\title{
ANALISIS KUALITAS LAYANAN E-LEARNING DENGAN METODE SERVICE QUALITY (SERVQUAL) DAN ANALYTICAL HIERARCHY PROCESS (AHP)
}

\author{
Theresiawati $^{1}$, Ati Zaidiah ${ }^{2}$, Ria Astriratma ${ }^{3}$, Henki Bayu Seta ${ }^{4}$ \\ Universitas Pembangunan Nasional Veteran Jakarta ${ }^{1,2,3,4}$ \\ Jalan RS. Fatmawati, Jakarta Selatan \\ Sur-el : theresiawati@upnvj.ac.id 1, atizaidiah@upnvj.ac.id², \\ astriratma@upnvj.ac.id ${ }^{3}$, henkiseta@upnvj.ac.id ${ }^{4}$
}

\begin{abstract}
One indicator of the success of developing and implementing e-learning in a university is user satisfaction, both lecturers and students. E-learning is a learning method to support the process of learning activities carried out online. This research was conducted to analyze the quality of blendeed learning services using the ServQual (Service Quality) and AHP (Analytical Hierarchy Process) methods. The ServQual method is to determine the perceptions and expectations of users of blendeed learning based on student perspectives based on the dimensions of assurance, empathy, responsiveness, reliability, usability and informativeness. To improve the quality of e-learning services, it is necessary to measure service quality using the SERVQUAL (Service Quality) method, to calculate the score gap between the perceived service quality assessment (performance) and the expected service quality. While the AHP (Analytical Hierarchy Process) method is used to determine the weighting value of each variable used in the study. So that efforts to improve the quality of higher education in particular can meet the demands and satisfaction of users.
\end{abstract}

Keywords: ServQual, AHP, e-Learning, Service quality

\begin{abstract}
Abstrak : Salah satu indikator keberhasilan pengembangan dan implementasi e-learning pada suatu perguruan tinggi adalah kepuasan pengguna baik dosen maupun mahasiswa. E-learning merupakan metode pembelajaran untuk menunjang proses kegiatan belajar yang dilakukan secara daring. Penelitian ini dilakukan untuk menganalisis kualitas layanan blendeed learning menggunakan metode ServQual (Service Quality) dan AHP (Analytical Hierarchy Process). Metode ServQual untuk mengetahui persepsi dan harapan pengguna blendeed learning berdasarkan perspektif mahasiswa berdasarkan dimensi assurance, empathy, responsiveness, reliability, usability dan informativeness. Untuk meningkatkan kualitas layanan e-learning perlu dilakukan pengukuran kualitas layanan dengan menggunakan metode SERVQUAL (Service Quality), melakukan perhitungan gap skor antara penilaian kualitas layanan yang dirasakan (kinerja) dengan kualitas layanan yang diharapkan. Sedangkan metode AHP (Analytical Hierarchy Process) untuk mengetahui nilai pembobotan dari setiap variabel yang digunakan dalam penelitian. Sehingga upaya peningkatan kualitas pendidikan perguruan tinggi khususnya dapat memenuhi tuntutan dan kepuasan pengguna.
\end{abstract}

Kata kunci: ServQual, AHP, e-Learning, Service quality

\section{PENDAHULUAN}

Penggunaan e-learning sebagai media pembelajaran daring memungkinkan pengguna memilih konten yang diminati dan disesuaikan dengan kecepatan dan kemampuan masing - masing individu. Konten - konten yang tersedia di LMS e-learning meliputi materi pembelajaran yang bersifat mandiri, dapat diakses kapan dan dimana saja saat dibutuhkan dengan menggunakan perangkat digital dan jaringan komputer. Materi pembelajaran pada LMS e- 
learning juga dapat disisipi oleh video, audio, live chat, forum diskusi, tugas, presentasi maupun ujian secara daring.

Berdasarkan penelitian [1], loyalitas pengguna e-learning dibentuk oleh kualitas layanan yang terdiri dari dimensi kualitas pengajaran, dimensi layanan administrasi, dimensi layanan dukungan dan dimensi kualitas sistem. Peningkatan kualitas layanan dari program tutorial online secara otomatis meningkatkan loyalitas siswa pengguna. Di bidang pendidikan, loyalitas dan kepuasan siswa dapat dicapai dengan memberikan kualitas layanan pendidikan yang baik [2].

Tiga indikator kualitas pengajaran yang paling penting adalah kompetensi, konsistensi penilaian tugas dan desain program tutorial online [1]. Salah satu penyebabnya adalah penggunaan media ajar yang kurang menarik, tidak interaktif dan belum tersedianya materi uji sebagai bahan evaluasi. Kepuasan dan kesetiaan pengguna terhadap sistem e-learning telah menjadi perhatian besar dari lembaga pendidikan [3]. Pada kenyataannya, peningkatan jumlah kursus yang ditawarkan dan pengguna tutorial online masih disertai dengan keluhan siswa tentang layanan tutorial online. Keluhan termasuk kesulitan dalam mengakses situs web tutorial online, kesulitan untuk menghubungi tutor, dan keaktifan tutor dalam berinteraksi serta memberikan umpan balik

Penggunaan learning management system pada Perguruan Tinggi merupakan sesuatu yang sangat lazim digunakan untuk mendukung proses pembelajaran pada perguruan tinggi. Tingkat keberhasilan pengembangan dan implementasi $e$ - learning pada perguruan tinggi dapat diukur dengan melakukan analisis kualitas layanan elearning berdasarkan persfektif pengguna (mahasiswa).

Service quality atau yang lebih dikenal dengan ServQual merupakan alat yang efektif untuk melakukan pengukuran kualitas layanan dari atribut masing - masing dimensi dengan cara menghitung gap antara persepsi konsumen terhadap layanan yang telah diterima dengan harapan terhadap yang akan diterima. Dimensi ServQual meliputi tangibles, reliability, responsiveness, assurance dan empathy [4]. Penelitian yang dilakukan oleh [5] terhadap kualitas pembelajaran tradisional berdasarkan persepsi siswa. Penelitian tersebut menghasilkan tiga dari lima dimensi ServQual (assurance, empathy dan reliability) signifikan.

Service quality dapat diperlakukan sebagai anteseden dari kepuasan pelanggan[6] dan sangat berpengaruh terhadap kepuasan pengguna[7]. ELearning service quality merupakan hasil perbandingan dalam penggunaan e-learning antara harapan pengguna dan persepsi kinerja terhadap layanan sistem informasi e-learning melalui karakterisasi layanan seperti intangibility, heterogeneity, inseparability and perish ability [8]. Tiga faktor yang mempengaruhi e-learning service quality diantaranya kepuasan pengguna, kualitas sistem, dan kualitas informasi [9]. Kepuasan pengguna akan meningkat dan pengguna tertarik dengan layanan e-learning jika memiliki konten yang stabil, mudah digunakan, serta memadai. Dan jika layanan e-learning dapat memberikan pengguna kemudahan untuk berdiskusi dengan 
para ahli ketika mereka membutuhkan bantuan, maka pengguna akan senang menggunakan layanan ini [10].

Penelitian yang dilakukan oleh [11], dimensi kualitas system e-learning merupakan triangle yang terdiri dari kualitas pengajar yang diwakili oleh dimensi assurance, empathy, responsiveness, dan reliability, kualitas dari LMS yang diwakili olah dimensi usability dan informativeness, serta kualitas dari materi perkuliahan yang diwakili oleh learning content.

Berdasarkan hal tersebut diatas, pertanyaan penelitian yang akan dijawab dalam penelitian ini adalah "Bagaimana kualitas layanan e-learning pada perguruan tinggi berdasarkan perspektif mahasiswa dengan mengukur gap score kualitas layanan yang dirasakan (kinerja) dengan kualitas layanan yang diharapkan menggunakan metode ServQual?

\section{METODOLOGI PENELITIAN}

Metodologi penelitian yang akan dilakukan dalam penelitian ini dimulai dari melakukan identifikasi masalah, studi literature dan penyusunan kerangka penelitian, menentukan dimensi service quality yang akan digunakan, melakukan pembuatan kuesioner serta menentukan responden yang akan di teliti yaitu mahasiswa. Setelah dilakukan pengumpulan data melalui kuesioner yang dilakukan secara online melalui lerning management system (LMS) e-learning dilakukan pengujian hasil kuesioner meliputi uji validitas, realibilitas, rekapitulasi data persepsi dan harapan pengguna, serta perhitungan gap antara persepsi dan harapan. Kemudian dilakukan pengolahan dan analisis menggunakan Servqual dan AHP, antara lain Analisis Nilai Servqual, Nilai Pembobotan dan Nilai Servqual Terbobot, Penentuan tingkat kualitas layanan, Penentuan faktor yang perlu ditingkatkan serta Rekomendasi Perbaikan.

Pendekatan yang digunakan merupakan pendekatan kuantitatif, untuk dapat menjelaskan hubungan antara variabel-variabel yang diteliti dengan mengumpulkan data-data numerik dari sampel penelitian yang kemudian dianalisis dengan menggunakan metode statistik tertentu. Pengumpulan data dalam penelitian kuantitatif ini menggunakan metode kuesioner yang diambil dari responden mahasiswa Universitas Pembangunan Nasional Veteran Jakarta selaku pengguna e-learning. Populasi dalam penelitian ini adalah mahasiswa UPN "Veteran". Jumlah sampel dalam penelitian ini sebanyak \pm 200 mahasiswa. Metode yang digunakan untuk melakukan pengolahan data yaitu menggunakan SPSS.

\section{HASIL DAN PEMBAHASAN}

\subsection{Uji validitas dan reliabilitas}

Kuesioner terdiri dari 23 daftar pertanyaan untuk variabel Harapan dan Persepsi sehingga secara keseluruhan terdapat 46 item pertanyaan. Kuesioner yang disusun menggunakan 5 poin skala likert. Uji validitas dan reliabilitas pada penelitian ini, menggunakan program Statistical Package for the Social Sciences (SPSS) versi 23.0. Nilai $r$ tabel untuk jumlah sampel sebesar $219(\mathrm{df}=217)$ adalah 0,133. Ringkasan hasil 
pengujian validitas dan reliabilitas kuesioner ditunjukkan pada Tabel - tabel dibawah ini.

Tabel 1. Uji Validitas Untuk Harapan Pengguna

Case Processing Summary

\begin{tabular}{|rl|r|r|}
\hline & & \multicolumn{1}{|c|}{ N } & \multicolumn{1}{c|}{$\%$} \\
\hline Cases & Valid & 219 & 100.0 \\
& Excluded $^{\text {a }}$ & 0 & .0 \\
& Total & 219 & 100.0 \\
\hline
\end{tabular}

a. Listwise deletion based on all variables in the procedure.

Tabel 2. Uji Validitas Untuk Persepsi Pengguna Case Processing Summary

\begin{tabular}{|ll|r|r|}
\hline & & \multicolumn{1}{|c|}{ N } & \multicolumn{1}{c|}{$\%$} \\
\hline Cases & Valid & 219 & 100.0 \\
& Excluded $^{\text {a }}$ & 0 & .0 \\
& Total & 219 & 100.0 \\
\hline
\end{tabular}

a. Listwise deletion based on all variables in the procedure.

Tabel 3. Hasil Uji Validitas dan Reliabilitas Untuk Harapan dan Persepsi Pengguna

\begin{tabular}{|c|c|c|c|}
\hline Variabel & Pertanyaan & $\begin{array}{l}C I- \\
C T\end{array}$ & $\begin{array}{c}\text { Cronbach's } \\
\text { Alpha }\end{array}$ \\
\hline \multirow[t]{8}{*}{ Assurance } & H1 & 0.788 & 0.890 \\
\hline & $\mathrm{H} 2$ & 0.776 & \\
\hline & H3 & 0.725 & \\
\hline & $\mathrm{H} 4$ & 0.742 & \\
\hline & $\mathrm{P} 1$ & 0.461 & 0.795 \\
\hline & $\mathrm{P} 2$ & 0.710 & \\
\hline & P3 & 0.623 & \\
\hline & $\mathrm{P} 4$ & 0.639 & \\
\hline \multirow[t]{8}{*}{ Empathy } & H5 & 0.756 & 0.883 \\
\hline & H6 & 0.752 & \\
\hline & $\mathrm{H} 7$ & 0.719 & \\
\hline & H8 & 0.754 & \\
\hline & P5 & 0.787 & 0.870 \\
\hline & P6 & 0.709 & \\
\hline & P7 & 0.644 & \\
\hline & P8 & 0.755 & \\
\hline \multirow[t]{4}{*}{ Responsiveness } & H9 & 0.806 & 0.893 \\
\hline & $\mathrm{H} 10$ & 0.776 & \\
\hline & H11 & 0.788 & \\
\hline & P9 & 0.661 & 0.802 \\
\hline
\end{tabular}

\begin{tabular}{|c|c|c|c|}
\hline Variabel & Pertanyaan & $\begin{array}{l}C I- \\
C T\end{array}$ & $\begin{array}{c}\text { Cronbach's } \\
\text { Alpha }\end{array}$ \\
\hline & P10 & 0.668 & \\
\hline & P11 & 0.616 & \\
\hline \multirow[t]{6}{*}{ Reliablity } & H12 & 0.541 & 0.806 \\
\hline & H13 & 0.720 & \\
\hline & H14 & 0.709 & \\
\hline & $\mathrm{P} 12$ & 0.459 & 0.751 \\
\hline & P13 & 0.652 & \\
\hline & P14 & 0.39 & \\
\hline \multirow[t]{8}{*}{ Tangible } & H15 & 0.776 & 0.890 \\
\hline & H16 & 0.755 & \\
\hline & H17 & 0.771 & \\
\hline & H18 & 0.747 & \\
\hline & P15 & 0.674 & 0.830 \\
\hline & P16 & 0.642 & \\
\hline & P17 & 0.641 & \\
\hline & P18 & 0.676 & \\
\hline Website & H19 & 0.700 & 0.908 \\
\hline \multirow[t]{9}{*}{ Content } & $\mathrm{H} 20$ & 0.804 & \\
\hline & $\mathrm{H} 21$ & 0.780 & \\
\hline & $\mathrm{H} 22$ & 0.816 & \\
\hline & $\mathrm{H} 23$ & 0.738 & \\
\hline & P19 & 0.673 & 0.886 \\
\hline & $\mathrm{P} 20$ & 0.791 & \\
\hline & $\mathrm{P} 21$ & 0.775 & \\
\hline & $\mathrm{P} 22$ & 0.750 & \\
\hline & P23 & 0.658 & \\
\hline
\end{tabular}

Hasil uji validitas menunjukkan bahwa dari 46 item pertanyaan pada kuesioner tersebut, r hitung Corrected Item - Total Correlation pada output SPSS bernilai positif dan lebih besar dari nilai $r$ tabel. Nilai $r$ tabel untuk 219 responden adalah sebesar 0,1333 sedangkan seluruh item pertanyaan diatas memiliki nilai alpha dikisaran 0,751. Dengan demikian dapat dikatakan bahwa kuesioner yang digunakan oleh penulis layak digunakan sebagai alat ukur dalam penelitian ini.

\subsection{Pengukuran SERVQUAL}

Tabel 4 berikut merupakan rekapitulasi data nilai harapan dan persepsi atas masingmasing atribut-atribut layanan sistem e-learning. 
Tabel 4. Gap Score SERVQUAL Atribut-Atribut Layanan E-learning

\begin{tabular}{|c|c|c|c|c|c|c|c|c|c|}
\hline \multirow[t]{2}{*}{ No } & \multirow[t]{2}{*}{ Atribut Kualitas } & \multicolumn{3}{|c|}{ Nilai Persepsi } & \multicolumn{3}{|c|}{ Nilai Harapan } & \multirow{2}{*}{$\begin{array}{l}\text { Gap } \\
\text { Score }\end{array}$} & \multirow{2}{*}{$\begin{array}{c}\text { Rata- } \\
\text { rata } \\
\text { Gap } \\
\text { Score }\end{array}$} \\
\hline & & Score & Average & $\%$ & Score & Average & $\%$ & & \\
\hline 1 & $\begin{array}{l}\text { Dosen memiliki } \\
\text { pengetahuan sesuai } \\
\text { bidangnya }\end{array}$ & 825 & 3.77 & 75.34 & 947 & 4.32 & 86.48 & -0.55 & -0.51 \\
\hline 2 & $\begin{array}{l}\text { Dosen bersifat adil dan } \\
\text { tidak memihak dalam } \\
\text { memberikan penilaian }\end{array}$ & 845 & 3.86 & 77.17 & 939 & 4.29 & 85.75 & -0.43 & \\
\hline 3 & $\begin{array}{l}\text { Dosen menjawab semua } \\
\text { pertanyaan Mahasiswa } \\
\text { secara menyeluruh }\end{array}$ & 826 & 3.77 & 75.43 & 944 & 4.31 & 86.21 & -0.54 & \\
\hline 4 & $\begin{array}{l}\text { Saya percaya dosen } \\
\text { memiliki pemahaman } \\
\text { mengenai materi yang } \\
\text { diberikan }\end{array}$ & 847 & 3.87 & 77.35 & 957 & 4.37 & 87.40 & -0.50 & \\
\hline 5 & $\begin{array}{l}\text { Dosen memperhatikan } \\
\text { dan peduli terhadap } \\
\text { mahasiswa }\end{array}$ & 782 & 3.57 & 71.42 & 929 & 4.24 & 84.84 & -0.67 & -0.63 \\
\hline 6 & $\begin{array}{l}\text { Dosen memahami } \\
\text { kebutuhan mahasiswa }\end{array}$ & 768 & 3.51 & 70.14 & 928 & 4.24 & 84.75 & -0.73 & \\
\hline 7 & $\begin{array}{l}\text { Dosen memberikan } \\
\text { penilaian terbaik untuk } \\
\text { mahasiswa }\end{array}$ & 828 & 3.78 & 75.62 & 945 & 4.32 & 86.30 & -0.54 & \\
\hline 8 & $\begin{array}{l}\text { Dosen mendorong dan } \\
\text { memotivasi Mahasiswa } \\
\text { untuk melakukan yang } \\
\text { terbaik }\end{array}$ & 812 & 3.71 & 74.16 & 936 & 4.27 & 85.48 & -0.56 & \\
\hline 9 & $\begin{array}{l}\text { Dosen menanggapi } \\
\text { kebutuhan Mahasiswa } \\
\text { dengan cepat dan efisien }\end{array}$ & 749 & 3.42 & 68.40 & 926 & 4.23 & 84.57 & -0.81 & -0.71 \\
\hline 10 & $\begin{array}{l}\text { Dosen bersedia } \\
\text { membantu mahasiswa } \\
\text { dalam memecahkan } \\
\text { masalah }\end{array}$ & 791 & 3.61 & 72.24 & 936 & 4.27 & 85.48 & -0.66 & \\
\hline 11 & $\begin{array}{l}\text { Dosen selalu } \\
\text { menanggapi pertanyaan } \\
\text { dan komentar } \\
\text { Mahasiswa }\end{array}$ & 787 & 3.59 & 71.87 & 931 & 4.25 & 85.02 & -0.66 & \\
\hline 12 & $\begin{array}{l}\text { Dosen secara konsisten } \\
\text { memberikan materi }\end{array}$ & 803 & 3.67 & 73.33 & 957 & 4.37 & 87.40 & -0.70 & -0.65 \\
\hline 13 & $\begin{array}{l}\text { Dosen dapat } \\
\text { dihandalkan }\end{array}$ & 770 & 3.52 & 70.32 & 918 & 4.19 & 83.84 & -0.67 & \\
\hline 14 & $\begin{array}{l}\text { Dosen Memperbaiki } \\
\text { informasi yang telah } \\
\text { diberikan bila diperlukan }\end{array}$ & 793 & 3.62 & 72.42 & 923 & 4.21 & 84.29 & -0.59 & \\
\hline 15 & $\begin{array}{l}\text { User interface Sistem e- } \\
\text { learning mudah } \\
\text { digunakan }\end{array}$ & 706 & 3.22 & 64.47 & 903 & 4.12 & 82.47 & -0.90 & -0.79 \\
\hline
\end{tabular}




\begin{tabular}{|c|c|c|c|c|c|c|c|c|c|}
\hline \multirow[t]{2}{*}{ No } & \multirow[t]{2}{*}{ Atribut Kualitas } & \multicolumn{3}{|c|}{ Nilai Persepsi } & \multicolumn{3}{|c|}{ Nilai Harapan } & \multirow{2}{*}{$\begin{array}{l}\text { Gap } \\
\text { Score }\end{array}$} & \multirow{2}{*}{$\begin{array}{c}\text { Rata- } \\
\text { rata } \\
\text { Gap } \\
\text { Score }\end{array}$} \\
\hline & & Score & Average & $\%$ & Score & Average & $\%$ & & \\
\hline 16 & $\begin{array}{l}\text { Sistem e-learning cepat } \\
\text { dan mudah diakses }\end{array}$ & 685 & 3.13 & 62.56 & 888 & 4.05 & 81.10 & -0.92 & \\
\hline 17 & $\begin{array}{l}\text { Sistem e-Learning } \\
\text { mencakup berbagai } \\
\text { kegiatan pembelajaran }\end{array}$ & 752 & 3.43 & 68.68 & 923 & 4.21 & 84.29 & -0.78 & \\
\hline 18 & $\begin{array}{l}\text { Sistem e-Learning } \\
\text { mudah dikelola oleh } \\
\text { Mahasiswa }\end{array}$ & 807 & 3.68 & 73.70 & 928 & 4.24 & 84.75 & -0.56 & \\
\hline 19 & $\begin{array}{l}\text { website e-learning } \\
\text { menggunakan fitur } \\
\text { multimedia }\end{array}$ & 758 & 3.46 & 69.22 & 910 & 4.16 & 83.11 & -0.70 & -0.54 \\
\hline 20 & $\begin{array}{l}\text { website e-learning } \\
\text { menyediakan informasi } \\
\text { yang bermanfaat }\end{array}$ & 841 & 3.84 & 76.80 & 933 & 4.26 & 85.21 & -0.42 & \\
\hline 21 & $\begin{array}{l}\text { website e-learning } \\
\text { menyediakan informasi } \\
\text { yang akurat }\end{array}$ & 812 & 3.71 & 74.16 & 917 & 4.19 & 83.74 & -0.48 & \\
\hline 22 & $\begin{array}{l}\text { website e-learning } \\
\text { menyediakan informasi } \\
\text { yang berkualitas }\end{array}$ & 792 & 3.62 & 72.33 & 922 & 4.21 & 84.20 & -0.59 & \\
\hline 23 & $\begin{array}{l}\text { Informasi pada website } \\
\text { e-learning relevan } \\
\text { dengan mata kuliah yang } \\
\text { diajarkan }\end{array}$ & 828 & 3.78 & 75.62 & 935 & 4.27 & 85.39 & -0.49 & \\
\hline
\end{tabular}

Berdasarkan tabel 4 diatas, nilai rata - rata persepsi terendah ditempati oleh kriteria "Sistem e-learning cepat dan mudah diakses" sedangkan nilai rata - rata persepsi tertinggi ditempati oleh "Saya percaya dosen memiliki pemahaman mengenai materi yang diberikan". Hal ini menandakan mahasiswa sangat menginginkan perbaikan kualitas untuk variabel assurance khususnya dosen memiliki pemahaman mengenai materi yang diberikan. Nilai persentase untuk dimensi persepsi responden atas layanan sistem e-learning berkisar antara 60 persen sampai 80 persen. Sedangkan persentase nilai harapan para responden terhadap layanan sistem e-learning, berada diantara 80 persen sampai 90 persen. Lebih lanjut, dengan membandingkan hasil dari kedua tabel tersebut, maka dapat dilihat kembali terdapat perbedaan antara tingkat harapan dan tingkat persepsi para responden terhadap atribut-atribut kualitas layanan sistem e-learning seperti terlihat pada gambar 1 berikut:

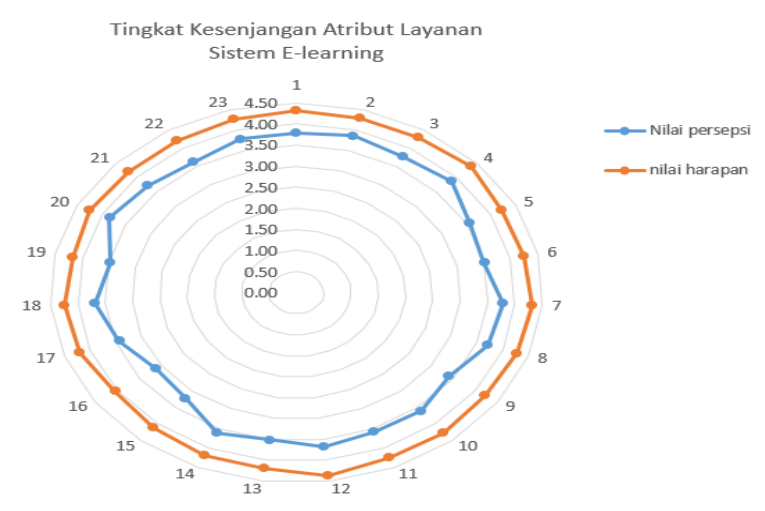

Gambar 1. Diagram Tingkat Kesenjangan Atribut Layanan 
Tabel 5. Hasil Analisis Uji Beda Harapan dan Persepsi Pengguna

\begin{tabular}{|c|c|c|c|c|c|c|c|c|c|}
\hline & & \multicolumn{5}{|c|}{ Paired differences } & \multirow[t]{3}{*}{$t$} & \multirow[t]{3}{*}{$d f$} & \multirow{3}{*}{$\begin{array}{c}\text { Sig } \\
\text { (2-tailed) }\end{array}$} \\
\hline & & \multirow[t]{2}{*}{ Mean } & \multirow[t]{2}{*}{$\begin{array}{c}\text { Std. } \\
\text { Deviation }\end{array}$} & \multirow[t]{2}{*}{$\begin{array}{l}\text { Std. } \\
\text { Error } \\
\text { Mean }\end{array}$} & \multicolumn{2}{|c|}{$\begin{array}{c}\text { 95\% Confidence } \\
\text { interval of the } \\
\text { difference }\end{array}$} & & & \\
\hline & & & & & Lower & Upper & & & \\
\hline Pair1 & TOTASSX - TOTASSY & 0.5068 & 1.1459 & 0.3872 & 0.4308 & 0.5828 & 13.091 & 875 & 0.000 \\
\hline Pair2 & TOTEMPX - TOTEMPY & 0.6255 & 1.2042 & 0.0406 & 0.5457 & 0.7054 & 15.373 & 875 & 0.000 \\
\hline Pair3 & TOTRESX - TOTRESY & 0.7092 & 1.2144 & 0.0473 & 0.6125 & 0.8023 & 14.970 & 656 & 0.000 \\
\hline Pair4 & TOTREX - TOTREY & 0.6575 & 1.1056 & 0.4314 & 0.5728 & 0.7422 & 15.234 & 656 & 0.000 \\
\hline Pair5 & TOTTAX - TOTTAY & 0.7899 & 1.2816 & 0.4330 & 0.7049 & 0.8749 & 18.242 & 875 & 0.000 \\
\hline Pair6 & TOTWCX - TOTWCY & 0.5351 & 1.2102 & 0.3365 & 0.4634 & 0.6069 & 14.632 & 1094 & 0.000 \\
\hline
\end{tabular}

Signifikansi pada 0,05

Hasil gap score ServQual berada pada posisi negatif sehingga dapat kembali disimpulkan jika nilai harapan responden tidak dapat diimbangi oleh nilai persepsinya sehingga berdampak pada nilai gap score yang negatif. Hal ini membuktikan jika layanan sistem elearning belum dapat memenuhi harapan para penggunanya.

\subsection{Uji Beda $T$}

Uji beda $\mathrm{T}$ digunakan untuk menguji penggunaan sampel yang berpasangan. Untuk menentukan hubungan antara harapan dan persepsi digunakan lima point skala likert. Untuk pertanyaan harapan, sikap responden yang sangat tidak setuju diwakili oleh point 1 (satu), sedangkan sikap responden yang sangat setuju diwakili oleh point 5 (lima). Untuk pertanyaan persepsi, sikap responden yang sangat tidak puas diwakili oleh poin 1 (satu), sedangkan sikap sangat puas diwakili oleh poin 5 (lima). Huruf "X" pada setiap variabel menyatakan harapan responden, sedangkan huruf "Y" menyatakan persepsi responden.

Tabel 5 menunjukkan antara harapan dan persepsi bagi responden terdapat perbedaan. Dengan melihat hasil Uji Beda $\mathrm{T}$ diatas yang menyatakan memang terdapat perbedaan hasil antara dimensi harapan dan persepsi, maka sesuai dengan hasil perhitungan SERVQUAL awal, terdapat perbedaan terhadap kualitas dimensi harapan dan dimensi persepsi responden dimana semua hasil gap score-nya menunjukkan nilai negatif.

\section{d. Perhitungan Pembobotan dengan AHP}

Setelah perhitungan gap, selanjutnya adalah pemberian bobot pada setiap gap atribut penelitian dengan menggunakan Analityc Hierarchy Process (AHP). Untuk mendapatkan bobot dari setiap atribut terlebih dahulu dicari Eigenvactor yang akan menjadi bobot dari setiap kriteria. Eigenvactor dijadikan sebagai Global Priorities (GP) untuk setiap kriteria. Gambar 2 menunjukkan GP dari tiap-tiap kriteria Servqual:

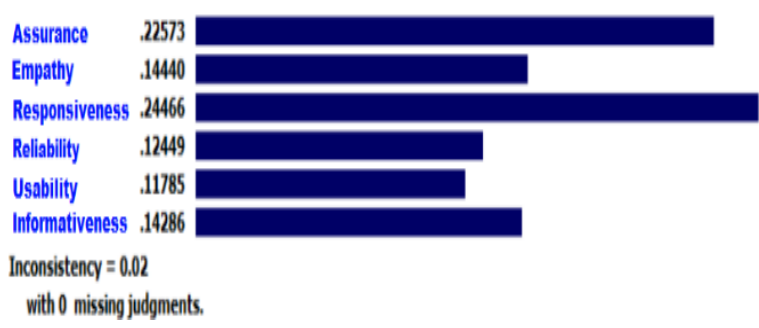

Gambar 2 Hasil Pembobotan Dimensi Servqual

Berdasarkan hasil pembobotan dimensi Servqual, terlihat bahwa kriteria responsiveness merupakan kriteria tertinggi yaitu sebesar 0.24466. Hal ini menandakan dimensi responsiveness memiliki pengaruh besar 
dibandingkan dengan kelima dimensi yang lain. Dimensi selanjutnya yaitu dimensi assurance dengan bobot 0.22573 , dimensi empathy dengan bobot 0.14440 , sedangkan kriteria dimensi informativeness dengan bobot 0.14286 , dimensi reliability dengan bobot 0.12449 dan usability dengan bobot 0.11785 . Besar rasio inconsistency adalah 0,02 kurang dari pada 0,1. Maka pembobotan kriteria utama tersebut sudah benar atau bisa dikatakan konsisten.

\subsection{Eigenvactor tiap kriteria di dalam dimensi atau Local Priorities (LP).}

\section{a. Analisa Bobot pada Dimensi Assurance}

Kriteria kualitas layanan berdasarkan nilai bobot pada dimensi Assurance. Berdasarkan tabel 6 hasil pembobotan dimensi assurance, rasio inconsistency sebesar 0.03 atau kurang dari 0.1 maka dapat dinyatakan pembobotan kriteria utama tersebut sudah benar atau bisa dikatakan konsisten.

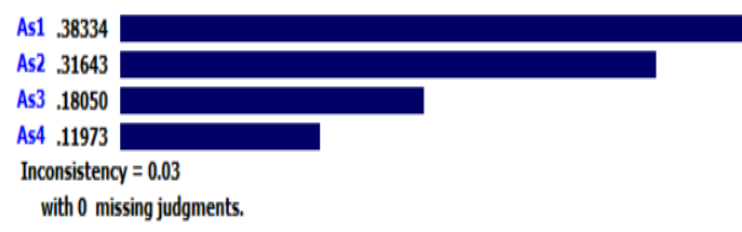

Gambar 3 Hasil Pembobotan Dimensi Assurance

Indikator Dosen memiliki pengetahuan sesuai bidangnya pada dimensi assurance menempati urutan pertama sebesar 0.38334 hal ini menyatakan dosen pengampu matakuliah harus memiliki pengetahuan dan sesuai dengan bidang yang dipahami oleh dosen tersebut. Sedangkan Dosen bersifat adil dan tidak memihak dalam memberikan penilaian berada pada nomor 2 dengan nilai 0.31643 . Untuk nomor 3 adalah Dosen menjawab semua pertanyaan Mahasiswa secara menyeluruh dengan nilai 0.18050 .
Dan yang terakhir adalah Dosen memiliki pemahaman mengenai materi yang diberikan dengan nilai 0.11973 .

b. Analisa Bobot pada Dimensi Empathy

Kriteria kualitas layanan berdasarkan nilai bobot pada dimensi Empathy. Berdasarkan gambar 4 hasil pembobotan dimensi empathy, rasio inconsistency sebesar 0.06 atau kurang dari 0.1 maka dapat dinyatakan pembobotan kriteria utama tersebut sudah benar atau bisa dikatakan konsisten.

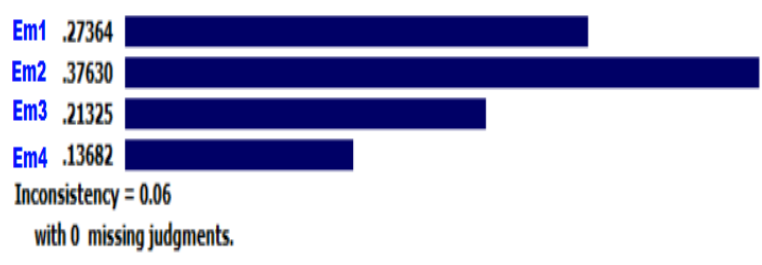

Gambar 4. Hasil Pembobotan Dimensi Empathy

Indikator Dosen memahami kebutuhan mahasiswa pada dimensi empathy menempati urutan pertama sebesar 0.37630 hal ini menyatakan dosen harus memahami kebutuhan setiap mahasiswa, karena mahasiswa memiliki tingkat kemampuan yang berbeda - beda dan harus peka terhadap kebutuhan mahasiswa. Sedangkan Dosen memperhatikan dan peduli terhadap mahasiswa berada pada nomor 2 dengan nilai 0.27364 . Untuk nomor 3 adalah Dosen memberikan penilaian terbaik untuk mahasiswa dengan nilai 0.21325. Dan yang terakhir adalah Dosen mendorong dan memotivasi Mahasiswa untuk melakukan yang terbaik dengan nilai 0.13682 .

c. Analisa Bobot pada Dimensi
Responsiveness


Kriteria kualitas layanan berdasarkan nilai bobot pada dimensi Responsiveness.

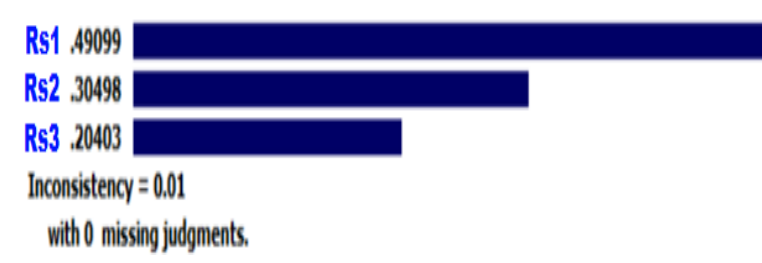

Gambar 5. Hasil Pembobotan Dimensi Responsiveness

d. Analisa Bobot pada Dimensi Reliability

Kriteria kualitas layanan berdasarkan nilai bobot pada dimensi Reliability.

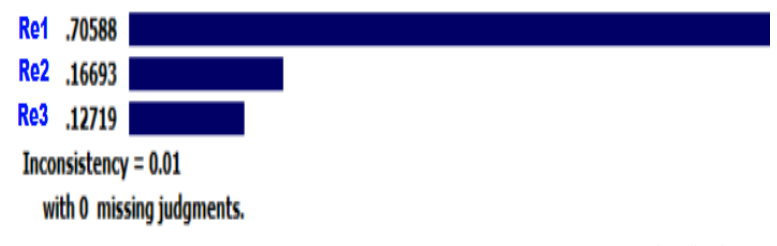

e. Analisa Bobot pada Dimensi Usability

Kriteria kualitas layanan berdasarkan nilai bobot pada dimensi Usability.

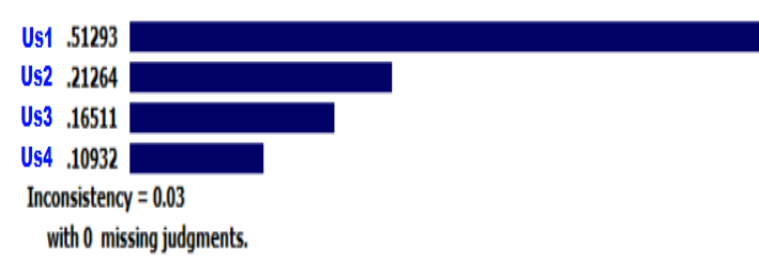

Gambar 7. Hasil Pembobotan Dimensi Usability

f. Analisa Bobot pada Dimensi Informativeness

Kriteria kualitas layanan berdasarkan nilai bobot pada dimensi Informativeness

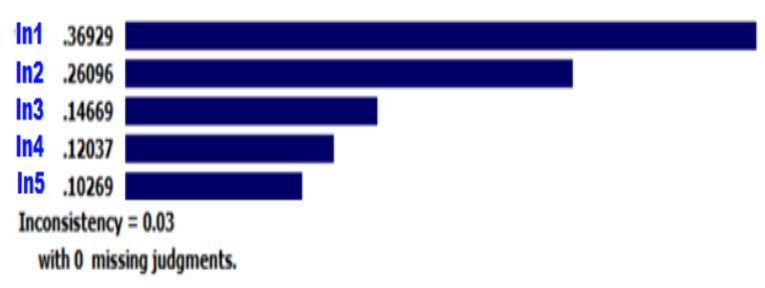

Tahap selanjutnya mencari nilai global priorities (GP) sebagai bobot kepentingan per atribut didalam dimensi service quality (servqual).

GP Sub Kriteria $=$ Nilai Kriteria Utama $\times$

$$
\text { LP sub kriteria }
$$

Hasil dari perolehan nilai GP kriteria dan sub kriteria dapat lebih jelas dilihat pada tabel 6:

Tabel 6. nilai GP kriteria dan sub kriteria

\begin{tabular}{lccc}
\hline \multicolumn{1}{c}{ Dimensi } & $\begin{array}{c}\text { Bobot } \\
\text { Dimensi } \\
(\boldsymbol{G P})\end{array}$ & $\begin{array}{c}\text { Bobot } \\
\text { Tiap } \\
\text { Kriteria } \\
(\text { LP })\end{array}$ & $\begin{array}{c}\text { GP Tiap } \\
\text { Kriteria }\end{array}$ \\
\hline Assurance & 0.22573 & 0.38334 & 0.08653 \\
& & 0.31643 & 0.07143 \\
& & 0.18050 & 0.04074 \\
Empathy & 0.14440 & 0.11973 & 0.02703 \\
& & 0.27364 & 0.03951 \\
& & 0.37630 & 0.05434 \\
Responsiveness & 0.24466 & 0.21325 & 0.03079 \\
& & 0.13682 & 0.01976 \\
Reliablity & & 0.30498 & 0.12013 \\
& 0.12449 & 0.70583 & 0.04462 \\
Usability & & 0.16693 & 0.08788 \\
& & 0.12719 & 0.01583 \\
& 0.11785 & 0.51290 & 0.06045 \\
& & 0.21264 & 0.02506 \\
& & 0.16511 & 0.01946 \\
& & 0.10932 & 0.01288 \\
& & 0.36929 & 0.05276 \\
& & 0.26096 & 0.03728 \\
& & 0.14669 & 0.02096 \\
& & 0.12037 & 0.01720 \\
& & 0.10269 & 0.01467 \\
\hline
\end{tabular}

\section{Perhitungan Nilai Serqual Terbobot}

Hasil perhitungan nilai servqual terbobot seperti tersebut pada tabel 7 dibawah ini

\section{Gambar 8. Hasil Pembobotan Dimensi}

\section{Informativeness}


Tabel 7. Nilai Serqual Terbobot

\begin{tabular}{|c|c|c|c|c|c|c|c|c|}
\hline $\begin{array}{c}\text { Kode } \\
\text { indikator }\end{array}$ & $\begin{array}{l}\text { Persepsi } \\
\text { (A) }\end{array}$ & $\begin{array}{c}\text { Harapan } \\
(B)\end{array}$ & $\operatorname{Gap}(A-B)$ & $\begin{array}{c}\text { Bobot } \\
\text { Dimensi } \\
(G P)\end{array}$ & $\begin{array}{c}\text { Bobot Tiap } \\
\text { Kriteria }(L P)\end{array}$ & $\begin{array}{l}\text { GP Tiap } \\
\text { Kriteria }\end{array}$ & $\begin{array}{c}\text { Gap } \\
\text { Terbobot }\end{array}$ & $\begin{array}{l}\text { Rank } \\
\text { Bobot }\end{array}$ \\
\hline As1 & 3.76700 & 4.32420 & -0.55720 & \multirow[t]{5}{*}{0.22573} & 0.38334 & 0.08653 & -0.04822 & \multirow{5}{*}{$\begin{array}{l}19 \\
15\end{array}$} \\
\hline As2 & 3.85800 & 4.28767 & -0.42967 & & 0.31643 & 0.07143 & -0.03069 & \\
\hline As3 & 3.77200 & 4.31050 & -0.53850 & & 0.18050 & 0.04074 & -0.02194 & \\
\hline As4 & 3.86800 & 4.36986 & -0.50186 & & 0.11973 & 0.02703 & -0.01356 & \\
\hline $\begin{array}{l}\text { Rata- } \\
\text { Rata }\end{array}$ & 3.81625 & 4.32306 & -0.50681 & & 0.25000 & 0.05643 & -0.02860 & \\
\hline Em1 & 3.57100 & 4.24201 & -0.67101 & \multirow[t]{5}{*}{0.14440} & 0.27364 & 0.03951 & -0.02651 & \multirow{5}{*}{$\begin{array}{r}14 \\
18 \\
11 \\
6\end{array}$} \\
\hline Em2 & 3.50700 & 4.23744 & -0.73044 & & 0.37630 & 0.05434 & -0.03969 & \\
\hline Em3 & 3.78100 & 4.31507 & -0.53407 & & 0.21325 & 0.03079 & -0.01645 & \\
\hline Em4 & 3.70800 & 4.27397 & -0.56597 & & 0.13682 & 0.01976 & -0.01118 & \\
\hline $\begin{array}{l}\text { Rata- } \\
\text { Rata }\end{array}$ & 3.64175 & 4.26712 & -0.62537 & & 0.25000 & 0.03610 & -0.02346 & \\
\hline Rs1 & 3.42000 & 4.20091 & -0.78091 & \multirow[t]{4}{*}{0.24466} & 0.49099 & 0.12013 & -0.09381 & \multirow{4}{*}{$\begin{array}{l}23 \\
20 \\
16\end{array}$} \\
\hline Rs2 & 3.61200 & 4.27397 & -0.66197 & & 0.30498 & 0.07462 & -0.04939 & \\
\hline Rs3 & 3.59400 & 4.25114 & -0.65714 & & 0.20403 & 0.04992 & -0.03280 & \\
\hline $\begin{array}{l}\text { Rata- } \\
\text { Rata }\end{array}$ & 3.54200 & 4.24201 & -0.70001 & & 0.33333 & 0.08155 & -0.05867 & \\
\hline Re1 & 3.66700 & 4.36986 & -0.70286 & \multirow[t]{4}{*}{0.12449} & 0.70588 & 0.08788 & -0.06176 & \multirow{4}{*}{$\begin{array}{r}22 \\
8 \\
3\end{array}$} \\
\hline $\operatorname{Re} 2$ & 3.51600 & 4.19178 & -0.67578 & & 0.16693 & 0.02078 & -0.01404 & \\
\hline Re3 & 3.62100 & 4.21461 & -0.59361 & & 0.12719 & 0.01583 & -0.00940 & \\
\hline $\begin{array}{l}\text { Rata- } \\
\text { Rata }\end{array}$ & 3.60133 & 4.25875 & -0.65742 & & 0.33333 & 0.04150 & -0.02840 & \\
\hline Us1 & 3.22400 & 4.12329 & -0.89929 & \multirow[t]{5}{*}{0.11785} & 0.51290 & 0.06045 & -0.05436 & \multirow{5}{*}{21} \\
\hline Us 2 & 3.12800 & 4.05479 & -0.92679 & & 0.21264 & 0.02506 & -0.02323 & \\
\hline Us 3 & 3.43400 & 4.21461 & -0.78061 & & 0.16511 & 0.01946 & -0.01519 & \\
\hline Us 4 & 3.68500 & 4.23744 & -0.55244 & & 0.10932 & 0.01288 & -0.00712 & \\
\hline $\begin{array}{l}\text { Rata- } \\
\text { Rata }\end{array}$ & 3.36775 & 4.15753 & -0.78978 & & 0.24999 & 0.02946 & -0.02497 & \\
\hline In1 & 3.46100 & 4.15525 & -0.69425 & \multirow[t]{6}{*}{0.14286} & 0.36929 & 0.05276 & -0.03663 & \multirow{6}{*}{17} \\
\hline In 2 & 3.84000 & 4.26027 & -0.42027 & & 0.26096 & 0.03728 & -0.01567 & \\
\hline In 3 & 3.70800 & 4.18721 & -0.47921 & & 0.14669 & 0.02096 & -0.01004 & \\
\hline In 4 & 3.61600 & 4.21005 & -0.59405 & & 0.12037 & 0.01720 & -0.01022 & \\
\hline In 5 & 3.78100 & 4.26941 & -0.48841 & & 0.10269 & 0.01467 & -0.00717 & \\
\hline $\begin{array}{l}\text { Rata- } \\
\text { Rata }\end{array}$ & 3.68120 & 4.21644 & -0.53524 & & 0.20000 & 0.02857 & -0.01594 & \\
\hline
\end{tabular}


Berdasarkan tabel 7 diatas memperlihatkan semua nilai bobot servqual bernilai negatif. Hal ini menandakan bahwa tingkat harapan pengguna elearning dalam hal ini adalah mahasiswa terhadap kualitas layanan yang diinginkan lebih tinggi dibandingkan dengan tingkat persepsi mahasiswa terhadap kualitas layanan e-learning yang diinginkan. Dimensi - dimensi diatas memiliki nilai gap antara 0.01594 sampai dengan -0.25867. Berikut ini merupakan urutan gap mulai dari tertinggi sampai dengan terendah yaitu nilai gap dimensi responsiveness -0.05867 , nilai gap dimensi assurance -0.02860 , nilai gap reliability -0.02840 , nilai gap empathy -0.02346 , nilai gap usability -0.02840 dan nilai gap terkecil yaitu dimensi informativeness sebesar -0.01594 .

Kriteria-kriteria kualitas layanan yang harus segera diperbaiki adalah kriteria yang memiliki nilai gap lebih besar yaitu :

1. Dimensi responsiveness dengan nilai rata - rata -0.05867 meliputi dosen menanggapi kebutuhan Mahasiswa dengan cepat dan efisien, dosen bersedia membantu mahasiswa dalam memecahkan masalah, dan dosen selalu menanggapi pertanyaan dan komentar Mahasiswa.

2. Dimensi assurance dengan nilai rata - rata 0.02860 meliputi dosen memiliki pengetahuan sesuai bidangnya, dosen bersifat adil dan tidak memihak dalam memberikan penilaian, dosen menjawab semua pertanyaan Mahasiswa secara menyeluruh dan kepercayaan mahasiswa jika dosen memiliki pemahaman mengenai materi yang diberikan.
3. Dimensi reliability dengan nilai rata - rata 0.02840 meliputi dosen secara konsisten memberikan materi, dosen dapat dihandalkan dan dosen Memperbaiki informasi yang telah diberikan bila diperlukan.

4. Dimensi empathy dengan nilai rata - rata 0.02346 meliputi Dosen memperhatikan dan peduli terhadap mahasiswa, dosen memahami kebutuhan mahasiswa, dosen memberikan penilaian terbaik untuk mahasiswa dan dosen mendorong dan memotivasi Mahasiswa untuk melakukan yang terbaik.

5. Dimensi usability dengan nilai rata - rata 0.02497 meliputi sistem e-learning memiliki user interface yang mudah digunakan, sistem elearning cepat dan mudah diakses, sistem eLearning mencakup berbagai kegiatan pembelajaran dan sistem e-Learning mudah dikelola oleh Mahasiswa.

6. Dimensi Informativeness dengan nilai rata rata $\quad-0.01594$ meliputi e-learning menggunakan fitur multimedia, e-learning menyediakan informasi yang bermanfaat, elearning menyediakan informasi yang akurat, elearning menyediakan informasi yang berkualitas dan Informasi pada e-learning relevan dengan mata kuliah yang diajarkan

\section{KESIMPULAN}

Berdasarkan hasil analisis diatas, maka diusulkan beberapa rancangan perbaikan sebagai berikut:

a. Dimensi responsiveness: nilai gap atribut 
terbesar dimiliki oleh atribut RS1 sebesar 0.09381 yaitu dosen menanggapi kebutuhan Mahasiswa dengan cepat dan efisien. Hal ini berarti stakeholder dalam hal ini mahasiswa menginginkan adanya kesediaan dosen membantu dan memberikan layanan yang cepat diantaranya merespon kebutuhan mahasiswa dengan cepat dan efisien. Selain itu dosen juga sebaiknya bertindak sebagai fasilitator dan motivator agar kebutuhan mahasiswa dapat terpenuhi dengan baik dan memotivasi mahasiswa untuk dapat meningkatkan semangat belajar.

b. Dimensi assurance: Nilai gap atribut terbesar yaitu As1 sebesar -0.04822 yaitu dosen memiliki pengetahuan sesuai bidangnya. Setiap dosen harus memiliki wawasan luas dan melakukan update pengetahuan terhadap bidang yang selama ini ditekuni misalnya dengan melakukan pelatihan - pelatihan, sertifikasi profesi, serta mengikuti kegiatan sharing knowledge melalui komunitas profesi dosen. Dosen yang senantiasa melakukan update pengetahuan akan memberikan pencerahan dan wawasan pengetahuan yang luas. Sehingga dosen dapat melakukan transformasi, mengembangkan dan menyebarkan ilmu pengatahuan melalui tri darma pendidkan tinggi antara lain bidang pengajaran, penelitian dan pengabdian kepada masyarakat.

c. Dimensi reliability: Nilai atribut terbesar yaitu atribut RE1 sebesar -0.06176 yaitu Dosen secara konsisten memberikan materi yang sesuai dengan rancangan kurikulum dan rencana pembelajaran semester (RPS) yang telah ditetapkan program studi. Materi yang diberikan harus disesuaikan dengan situasi dan kondisi serta kebutuhan industri atau tuntutan dunia pekerjaan baik sekarang maupun dimasa yang akan datang.

d. Dimensi empathy: Nilai atribut terbesar yaitu EM2 bernilai -0.03969 yaitu Dosen memahami kebutuhan mahasiswa. Seorang dosen harus memahami kemampuan, kebutuhan masing - masing mahasiswa agar dosen dapat menentukan metode pembelajaran yang akan berdampak baik kepada mahasiswa. Kebutuhan setiap mahasiswa di dalam kelas akan berbeda, sehingga dibutuhkan kepekaan seorang dosen untuk memahami kebutuhan setiap mahasiswanya. Salah satu cara untuk menumbuhkan empati antara dosen dengan mahasiswa adalah dengan senantiasa menjaga komunikasi yang baik dan memberikan perhatian kepada setiap mahasiswa. Sehingga akan tiimbul rasa saling menghargai dan mempererat hubungan antara dosen dan mahasiswa.

e. Dimensi usability: Nilai atribut terbesar yaitu atribut TA1 sebesar -0.05436 yaitu sistem e-learning memiliki user interface yang mudah digunakan. User interface merupakan tampilan website atau aplikasi perangkat lunak untuk pengguna sehingga pengguna dapat mengkomunikasikan fitur yang tersedia, berinteraksi, menampilkan informasi aplikasi serta user dapat memahami dan mampu menggunakan sistem tersebut dengan baik. Dalam hal ini 
user interface e-learning tidak hanya memperhatikan fungsionalitas dan tampilan yang baik tetapi juga pengalaman menyenangkan yang dirasakan pengguna saat menggunakan e-learning. Contohnya membuat suatu konten yang mudah untuk di maneuver ketika mahasiswa menggunakan user interface dengan cara mengggeser layar, menekan tombol atau mengklik tombol menggunakan mouse. Pengguna elearning saat ini banyak yang mengakses elearning menggunakan perangkat seluler. Sehingga dibutuhkan user interface yang dapat dengan mudah diakses melalui perangkat seluler seperti tablet atau smartphone. Sehingga dibutuhkan desain antar muka yang responsive sehingga tampilan website dapat secara otomatis menyesuaikan dengan ukuran dan resolusi layar perangkat seluler. Pengguna e-learning menginginkan kontrol yang mudah digunakan dan membuat proses pembelajaran lebih cepat dan nyaman.

f. Dimensi informativeness: Nilai atribut terbesar yaitu WC1 sebesar -0.03663 yaitu website e-learning menggunakan fitur multimedia. Fitur multimedia meliputi konten audio, konten visual maupun konten audiovisual. Dengan adanya fitur multimedia akan menghasilkan media pembelajaran yang interaktif sehingga materi atau informasi antara dosen dan mahasiswa dapat tersampaikan dengan baik dan terjadi komunikasi aktif sehingga akan mempermudah proses pembelajaran. LMS e-learning mendukung paket pembelajaran elektronik dengan menggunakan berbagai macam format seperti teks, animasi, audio dan video. Salah satunya adalah menggunakan SCORM atau Shareble Content Object Reference Model. Untuk membuat konten pembelajaran menggunakan fitur multimedia SCORM terdapat beberapa tahapan yaitu membuat materi - materi pembelajaran dan menyatukannya dengan content creator (Xerte) serta memasang konten kedalam Learning Management System (LMS).

\section{DAFTAR PUSTAKA}

[1] Ayuni, D., \& Mulyana, A.. Applying Service Quality Model as a Determinant of Success in E-learning: The Role of Institutional Support and Outcome Value. Review of Integrative Business and Economics Research, 8, 145-159. 2019.

[2] Mohamad, M., \& Awang, Z. Building corporate image and securing student loyalty in the Malaysian higher learning industry. The Journal of International Management Studies, 4(1), 30-40. 2009.

[3] Dehghan, A., Dugger, J., Dobrzykowski, D., \& Balazs, A.. The antecedents of student loyalty in online programs. International journal of educational management. 2014.

[4] Parasuraman, A., Zeithaml, V. A., \& Berry, L. L., Servqual: A multiple-item scale for measuring consumer perceptions of service quality. Journal of retailing, 64(Spring), 1240. 1988.

[5] Stodnick, M, et al.,. Using SERVQUAL to measure the quality of the classroom experience. Decision Sciences Journal of Innovative Education. 6(1), 115-133. 2008.

[6] De Ruyter, K., Wetzels, M., Lemmink, J., \& Mattson, J. The dynamics of the service delivery process: a value-based approach. International journal of research in marketing, 14(3), 231-243.1997. 
[7] Sureshchandar, G. S., Chandrasekharan Rajendran, and R. N. Anantharaman., The relationship between service quality and customer satisfaction-a factor specific approach. Journal of services marketing, no. 4. 363-379. 2002.

[8] Yener, D., Students' Perceived Service Quality of Distance Learning Course in a Dual-Mode Education System. 2013.

[9] Rahman, Nur Amirah Abd, and Nor Hayati Abdul Hamid., E-learning service quality. International Conference on Research and Innovation in Information Systems (ICRIIS). IEEE. 1-6. 2017.

[10] Chen, L. H., \& Kuo, Y. F., Understanding e-learning service quality of a commercial bank by using Kano's model. Total Quality Management, 22(1), 99-116. 2011.

[11] Theresiawati, Seta, H. B., Hidayanto, A. N., \& Abidin, Z., Variables Affecting ELearning Services Quality In Indonesian Higher Education: Students'perspectives. Journal of Information Technology Education, 19. 2020. 